\title{
THE CONCEPT AND CONTENT OF THE RIGHT TO PROFESSIONAL LEGAL ASSISTANCE
}

\author{
Mehdiyev Polad Aley - doctoral student of the "Constitutional Law" Department \\ of Baku State University
}

УДК 342.7

DOI 10.32782/EP.2021.2.7

The article states that the legislative acts of the
Republic of Azerbaijan do not provide a legal defi-
nition of «legal assistance» and «the right to profes-
sional legal assistance». The problem of the right to
professional legal assistance has long been the subject
of research by legal scholars and remains unresolved
today. There are many positive aspects in each of the
definitions of the right to professional legal assistance
in the legal literature. However, since these definitions
do not cover all aspects of the right to professional le-
gal assistance, it is considered expedient for the author
to give a new definition of the right to professional
legal assistance.
Keywords: Azerbaijan Republic, state, constitu-
tion, concept, law.

The explanatory dictionary of the Azerbaijani language states that the word «aid» means «to help someone with something» [1]. The need for help is objective. Article 143 «Leaving in danger», of the Criminal Code of the Republic of Azerbaijan, which came into force on September 1, 2000, envisages: «Wittingly leaving a person without help, whose life or health is in danger and deprived opportunities to arrange the self-preservation in cases, if guilty had an opportunity to assist this person and was obliged to take care, or had resulted by putting the life or health of the person in danger - shall be punished by fine of one thousand to one thousand five hundred manats, or by corrective work for the term of up to one year, or imprisonment for the term of up to six months" [2].
Assistance should be as appropriate as possible to the needs of the subjects to whom it is addressed. The goals of seeking help and assistance should be as close as possible. Separation of these goals does not allow to achieve the intended (expected) result. When goals and outcomes do not coincide, abuse can occur when providing assistance.

Assistance may not be provided in an abstract or vague manner according to the scope of the subjects.

The following 12 (twelve) types of assistance are distinguished in scientific literature and mass media, including Internet information resources:

1) welfare assistance;

2) financial assitance;

3) medical care;

4) technical assistance;

5) social aid;

6) monetary assistance;

7) non- repayable aid;

8) humanitarian aid;

9) charitable assistance;

10) veterinary assistance;

11) sponsorship assistance;

12) legal assistance.

As you can see, one type of assistance is legal assistance. D.V.Talanov notes: "The term "legal" added to the word "assistance" indicates that this type of activity is enshrined in law, has certain consequences, is not out of control and is reinforced by legal action" [3, p. 11]. 


\section{Теорія, історія держави і права, конституційне право}

Legal aid reflects the level of the general legal culture of the society. Let's look at the concept of legal aid, which is a movement of special legal significance, a very necessary element of the mechanism for ensuring human and civil rights and freedoms, an important legal tool.

Legislative acts of the Republic of Azerbaijan do not provide a legal definition of "legal assistance". In the most general terms, legal assistance is defined as the assistance of one entity to another in the exercise of its rights and the performance of its duties. In other words, legal assistance is the "joining" of an external resource to resolve a legal conflict together over a period of time.

The problem of legal aid has long been the subject of research by legal scholars and remains not fully resolved today.

According to D.V.Talanov, "legal assistance is organizational, welfare and intellectual assistance carried out by the state bodies, officials, citizens and their associations through the forms prescribed by law and logically safe means in relation to entities that have lost the ability to act independently or are unable to do so, and who want to prevent or eliminate socially dangerous, crisis situations" [3, p. 11].

According to Panchenko, «providing legal assistance to a person is a targeted, professional assistance provided by legal means for the realization of a person's rights and freedoms in a problematic legal situation» [4, p. 19].

According to V.S.Kashkovsky, "legal assistance is assistance provided as a result of a lawyer's professional activity to prevent violations of the rights, freedoms and legitimate interests of legal entities, to eliminate or reduce the negative consequences of such violations and to restore the necessary position of the legal entity.

The independence of legal aid as a means of the rights, freedoms and legitimate interests of the individual, its inability to be equated with any other guarantees in the realization of human and civil rights and freedoms, is conditioned by the fact that it represents professional legal support in the implementation of the rights, freedoms and legitimate interests of a particular person in the form of full or partial replacement of his legal activity or preparation for it" [5, p. 8].

The common thing to understand the legal aid is that the assistance provided to the addressee is needed as a functional means of overcoming a dangerous or unavoidable situation.

The content of legal assistance is qualified assistance from outside (abroad) to ensure the realization of the interests or needs of the subjects, which are difficult to obtain in person.

An important feature of legal aid is that it is targeted.

The basis for the provision of legal assistance is the inability of the recipient to act independently in a specific or presumed social situation. A person in need of legal assistance may not be able to act independently for the following reasons:

1) he/she has no ability to act;

2) his/her physical condition does not allow him/her to act independently;

3) he/she cannot act independently due to his/her psychological condition;

4) it is impossible to act independently due to lack of information;

5) he/she cannot act independently due to lack of education.

Legal aid is manifested in the active actions of the subjects and, as a rule, begins with a request or proposal for assistance. Legal aid is usually provided by the competent authorities.

According to M.V.Kratenko, ,the subject of legal assistance is the realization of the right or obligation to provide and implement a specific service, tool, method that contributes to the functional effectiveness of the recipient, under certain conditions or unconditionally" [6, p. 21].

Legal aid is not a substitution or replacement of the activity of one subject (person receiving legal aid) with another. The person receiving legal assistance must always act in the direction of the legally significant actions of his choice.

Legal aid has a special implementation mechanism, including a strictly regulated procedure that requires the determination of the competence or professionalism of the relevant entities. It is from this perspective that 
it is possible to specialize assistance as a legitimate action.

Article 61 of the first Constitution of the independent Azerbaijan Republic, entitled „The Right to Legal Aid”, which was drafted under the leadership of national leader Heydar Aliyev and adopted by referendum on November 12, 1995, envisages:

„everyone shall have the right to high quality legal aid.

In cases provided by law, legal assistance is provided free of charge at public expense.

Everyone shall have the right to the assistance of a lawyer from the moment he is arrested, detained or charged with a crime" [7].

As can be seen, the Basic Law of the Republic of Azerbaijan, authored by national leader Heydar Aliyev, reflects the right of everyone to receive high-quality legal assistance. National leader Heydar Aliyev rightly stated that „our Constitution reflects the historical traditions and features of the Republic of Azerbaijan. It will ensure the establishment of a democratic rule of law in the Republic of Azerbaijan, the rights and freedoms of all citizens. This is our Constitution, the Constitution of the independent Azerbaijan Republic".

Professor Z.A.Asgarov rightly notes that „the Constitution of the Republic of Azerbaijan widely reflects the ideas and values that determine the direction of development of modern civil society and form the basis of the constitutional system, close connection of the state and society with the law; respect for human identity and dignity; participation of the people in the implementation of government functions through the democratic formation of state authorities; existence of mechanisms for effective protection of human rights; ensuring pluralism in the political system; to achieve social justice, commitment to universal values, harmonization of national legislation with international law, etc." [8].

One of the most important achievements in the implementation of the provisions of the Constitution has been the development of a high-quality legal aid institution. High-quality legal assistance can be provided only by a lawyer with higher education, ie a professional with special legal knowledge, skills and habits. It can be concluded that everyone in the Republic of Azerbaijan has the right to receive professional legal assistance.

By guaranteeing the right to professional legal assistance, the Republic of Azerbaijan undertakes to provide the necessary mechanism for the realization of this right, to create conditions for the training of qualified lawyers capable of providing various types of legal assistance to citizens and to ensure high quality legal assistance.

As an institution enshrined in the Constitution, the right to professional legal assistance is inextricably linked with the essence of a democratic state governed by the rule of law and reflects the complex relationship between the individual and the government to ensure everyone's real access to high quality legal assistance.

The right to professional legal assistance is one of the rights that form the legal basis for all legal systems (the legal system means "the internal structure expressed in the unity and harmonization of legal norms in force in the state, as well as the division of law into relatively independent parts") [9, p. 202] is protected at a high level.

The essence of the right to professional legal assistance has its own (special) developmental dialectic, moving from form to content. Historically, there has been an increase in the legal arsenal of legalization of assistance procedures, optimization of its means, conditions and guarantees.

Below are given the definitions of the right to professional legal assistance by scientists.

According to A.S.Pleten, ,the right to professional legal assistance means that eberyone has the right to apply to specialized entities entitled to qualified legal assistance to protect their endangered or actually violated rights in order to ensure their constitutional rights in accordance with internationally recognized principles" [10, p. 10-11].

According to Y.S.Lyubovenko, «the right to professional legal assistance means that it is guaranteed by the constitution that everyone shall have right to receive necessary information, consultation and practical aid on a contractual basis (repayable and non repayable) or free of charge in realization of 


\section{Теорія, історія держави і права, конституційне право}

the rights, freedoms and legitimate interests officially provided by entities that are formally indebted to it» [11, p. 17-18].

The opinion of N.R.Mukhudinova, who defines the right to professional legal assistance in criminal proceedings, is more interesting. She believes that "professional legal assistance in criminal proceedings is the activity of persons (subjects) authorized by law in a timely manner, in accordance with the law, using the necessary legal means in accordance with the procedural situation and the requirements of the law. It is necessary to assist in the protection of the rights, freedoms and legitimate interests of all, the restoration of violated rights, and the prevention of unlawful, unjustified restriction of rights, freedoms and legitimate interests» $[12$, p. 8].

In the objective sense, the right to professional legal assistance in criminal proceedings means «an interdisciplinary legal institution that regulates the right of everyone with a constitutional right to high quality legal assistance, combining the norms of constitutional law, criminal procedure law and other areas of law. In a subjective sense, this right, as a specialized legal aid, embodies the type and extent of possible conduct aimed at benefiting a person in criminal proceedings» [12, p. 14].

There are many positive aspects in each of the definitions of the right to professional legal assistance in the legal literature. However, I think that these concepts do not cover all aspects of the right to professional legal assistance, and therefore we consider it appropriate to define the right to professional legal assistance as follows:

«The right to professional legal assistance is a state gurantee provided through normative legal acts for necessary assistance from a lawyer with higher education who has legal knowledge, skills and habits, allowing everyone effective protection, including the protection of their rights and legitimate interests with the application of acts included in the legislative system of the Republic of Azerbaijan».

The definition of the right to professional legal assistance reflects its content. The content of the mentioned right includes the State guarantee for the effective protection of the rights and legitimate interests of individuals provided through normative legal acts and implementation of the said state guarantee providing necessary assistance related to the application of acts included in the legislative system of the Republic of Azerbaijan, through a lawyer with higher education who has legal knowledge, skills and habits.

\section{BIBLIOGRAPHIC REFERENCES}

1. Yardim. https://obastan.com/ yard $\% \mathrm{C} 4 \% \mathrm{~B} 1 \mathrm{~m} / 42698 / ? \mathrm{l}=\mathrm{az}$

2. Azərbaycan Respublikasının Cinayət Məcəlləsi. http://e-qanun.az/framework/46947

3. Таланов Д.В. Правовая помощь как объект общетеоретического анализа: Автореф. ... дисс. канд. юр. наук. Нижний Новгород - 2011, $35 \mathrm{c}$.

4. Панченко В.Ю. Юридическая помощь личности: общетеоретический аспект: Автореф. дис... канд. юрид. наук. Красноярск, 2004.- 33 с.

5. Кашковский В.С. Юридическая помощь как правовая категория и социально-правовое явление: вопросы теории и практики: Автореф. дисс. ... канд. юр. наук. Тамбов, 2009, 25 с.

6. Кратенко М.В. Предмет договора об оказании юридической помощи // Юрист. - 2005. - № 1 . - с. 20-24

7. Azərbaycan Respublikasının Konstitusiyası // 12 noyabr 1995-ci ildə qəbul edilmişdir (24 avqust 2002-ci il, 18 mart 2009cu il və 26 sentyabr 2016-c1 il tarixdə olan dəyişiklik və əlavələr). - Bakı: Hüquq Yayın Evi, - 2017, - 92 s.

8. Osgərov Z.A. Heydər Đliyevin müəllifi olduğu Konstitusiya hüquqi, demokratik və dünyəvi dövlətin inkişafının əsas təminatçısıdır. «Azərbaycan» qəzeti, Bakı, 2009, 1 may

9. Xrapanyuk V.N. Dövlət və hüquq nəzəriyyəsi (ixtisarla) / Rus dilindən tərcümə edənlər Həmid Baratlı və İlham Đsədov. Bakı: Qanun, 2007, 248 s.

10. Плетень А.С. Конституционное право на бесплатную юридическую помощь и механизм его реализации в современной России: Автореф. ... дисс. канд. юр. наук. Москва, 2008, 26 с.

11. Аюбовенко Е.С. Конституционное право на получение квалифицированной юридической помощи и механизм его гарантирования (Российский и зарубежный 
опыт): Автореф. дисс. ... канд. юр. наук. Москва, 2008, 30 с.

12. Мухудинова Н.Р. Обеспечение конституционного права каждого на получение квалифицированной юридической помощи в российском уголовном процессе: Автореф. дисс. ... канд. юр. наук. Москва, 2006, $31 \mathrm{c}$.

Мехдиев Полад Алей оглу - докторант каббедри Конституционного права Бакинского государственного университета ПОНЯТИЕ И СОДЕРЖАНИЕ ПРАВА ПРОФЕССИОНАЛЬНОЙ ЮРИДИЧЕ-

\section{СКОЙ ПОМОЩИ}

В статье указывается, что законодательные акты Азербайджанской Республики не содержат юридического определения по- нятий «юридическая помощь» и «право на профессиональную юридическую помощь». Проблема права на профессиональную юридическую помощь давно является предметом исследования ученых-юристов, и до сих пор остается нерешенной. В каждом из определений права на профессиональную юридическую помощь в юридической литературе, есть много положительных аспектов. Однако, поскольку эти определения не охватывают все аспекты права на профессиональную юридическую помощь, автор считает целесообразным дать новое определение права на профессиональную юридическую помощь.

Ключевые слова: Азербайджанская Республика, государство, конституция, понятие, право. 